\title{
Retrato y memoria colectiva: nuevos \\ desafíos en torno al \\ estudio de la retratística \\ monjil novohispana
}

\author{
Portraiture and Collective Memory: Nerw Challenges \\ around the Study of Nun Portraits in New Spain
}

DOI: https://doi.org/10.22380/20274688.1440

Recibido: 30 de julio del 2020

Aprobado: 15 de octubre del 2020
ADRIANA GUADALUPE ALONSO RIVERA*

Universidad Nacional Autónoma de México adriana.alonso.curaduria@gmail.com

\section{R E S U M $\quad \mathbf{E} \quad \mathbf{N}$}

El presente estudio pretende establecer una ruta por los distintos modos en los que la historiografía del arte novohispano se ha acercado al fenómeno del retrato corporativo, inscrito en el contexto monacal femenino, ofreciendo un panorama general de los problemas que tienden a suscitarse al momento de abordar la serie de estrategias calculadas o convenciones formuladas ex profeso para este conjunto de

* Candidata a doctora y especialista en Historia del Arte de la Facultad de Filosofía y Letras y el Instituto de Investigaciones Estéticas de la Universidad Nacional Autónoma de México (UNAM). Se desempeña como catedrática de la Licenciatura en Historia del Arte de la Universidad de las Américas Puebla. Su línea de investigación se centra en los usos de la imagen para afianzar modelos de espiritualidad y filiación corporativa en Nueva España en el siglo XVIII, concretamente en lo que respecta a la orden de agustinas recoletas. Forma parte del Seminario de investigación de pintura de caballete de la Escuela Nacional de Conservación, Restauración y Museografía "Manuel del Castillo Negrete" (ENCRyM) y del seminario Los conventos de monjas: arquitectura y vida cotidiana del virreinato a la posmodernidad del Instituto Nacional de Antropología e Historia (INAH), entre los más importantes. Asesora académica del Museo Universitario Casa de los Muñecos de la Benemérita Universidad Autónoma de Puebla (BUAP). 
representaciones. Lo anterior con el fin de trascender los géneros totalizantes en los que dichos retratos han solido aglutinarse, como es el caso de "monjas coronadas" o "pintura religiosa del siglo XviII". Asimismo, el artículo pone en discusión los prejuicios en torno a una supuesta calidad pictórica en función del potencial mimético y las cualidades decorativas de estas representaciones, promoviendo así nuevos ejes de investigación que evidencien sus propias variables, comportamientos y relaciones, desde enfoques teóricos, formales, corporativos y experienciales particulares.

Palabras clave: retrato corporativo, Nueva España, vida conventual femenina, retratos de monjas, arte novohispano, monjas coronadas.

\section{$\begin{array}{llllllll}\mathbf{A} & \mathbf{B} & \mathbf{S} & \mathbf{T} & \mathbf{R} & \mathbf{A} & \mathbf{C} & \mathbf{T}\end{array}$}

This research attempts to present a journey through the different methods New-Spain art historiography has approached the corporate portraiture phenomenon inscribed in the female monastic context, displaying a general overview of the issues that tend to take place when addressing the series of calculated or conventional strategies formulated expressly for this set of representations. Thus, it goes beyond totalitarian genders such portraitures have agglutinated, such as "crowned nuns" or "religious painting of the 18th century". In addition to it, the article questions prejudices around an alleged pictorial quality in function of the mimetic potential and the decorative features of these representations, encouraging new research axes evidencing their own variables, behaviors, and relations from particular theoretical, formal, corporate, and experiential approaches.

Keywords: corporate portraiture, New Spain, nunnery life, nun portraits, crowned nuns, art in New Spain.

\section{Introducción}

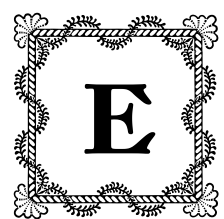

n la historiografía del arte novohispano, el retrato ha corrido la suerte de ser analizado a partir de una serie de criterios regidos, ya sea por la semejanza con su modelo, o por la presencia de una serie de elementos relacionados con la identidad individual del personaje representado. En lo relativo al estudio de los retratos inscritos en el contexto monacal femenino, la categoría "monjas coronadas" ha aglutinado al conjunto de representaciones de profesión, muerte y homenaje, con fines ampliamente recopilatorios, lo cual ha sido de suma utilidad para su ubicación y posterior clasificación. Sin embargo, dicha categoría suele excluir 
el análisis de las tradiciones visuales y el modo en el que estas incidieron en la configuración formal de los retratos. Asimismo, ha puesto poco énfasis en los contextos corporativos para los que los fueron producidos, reduciendo el estudio de sus usos y funciones a la mención de los lugares en los que se situaron, es decir, en el interior de los espacios familiares y conventuales. El presente estudio pretende establecer una ruta por los distintos modos en los que se ha configurado la mirada respecto al retrato y concretamente al retrato religioso corporativo, ofreciendo un panorama general de los problemas que pueden suscitarse al momento de abordar la serie de estrategias calculadas o "convenciones" presentes en el conjunto de representaciones retratísticas producidas en el ámbito monacal femenino novohispano. De este modo, se propone analizar los retratos producidos en dicho contexto desde una óptica delimitada y puesta en relación con los postulados espirituales y la vivencia cotidiana de sus distintos carismas regulares ${ }^{\mathrm{I}}$, valiéndose para este fin de un complejo aparato de recursos y discursos retóricos y visuales. Lo anterior propiciará que el análisis de la pintura conventual en Nueva España, e incluso en otras latitudes, pase de ser únicamente mencionado y caracterizado dentro de los géneros "monjas coronadas" o "pintura religiosa del siglo Xvin", a formar parte de una serie de investigaciones que evidencien sus propias variables, comportamientos y relaciones, a partir de su problematización desde enfoques formales, iconográficos, espirituales, históricos y experienciales particulares.

\section{El régimen escópico moderno y su preocupación por la perfección mimética}

Martin Jay, historiador y filósofo estadounidense, se ha preocupado por caracterizar los modos en los que se ha configurado la mirada a lo largo de las distintas épocas delineadas fundamentalmente por la historia de las ideas y la historia del arte. En su obra Campos de fuerza hace referencia al concepto de régimen escópico (222), el cual fue propuesto inicialmente por Christian Metz, para referirse al

I En términos teológicos, se entiende por carisma un don espiritual especial que el Espíritu Santo concede a los cristianos para edificar la Iglesia o extender el reino de Dios. Los Padres de la Iglesia reflexionaron en torno a los distintos carismas de gobierno bajo los cuales los miembros de las órdenes monásticas rigieron su vida cotidiana y desarrollaron su espiritualidad. En este sentido, aseguraron que aquellos dones que les son inspirados a las distintas comunidades de religiosos y religiosas, toman forma por medio de sus reglas y constituciones, protegiendo así a la institución monacal y garantizando su permanencia e indefectibilidad (Maroto 462-463, 467). 
hecho de que la mirada se encuentra condicionada por cierta estructura dominante, determinada por aspectos de carácter histórico, cultural y epistémico. Jay añade a la reflexión la posibilidad de no haber un único régimen imperante, sino varios que coexisten paralelamente a este, oponiéndosele incluso, cuestión que pone en duda la existencia de una concepción "escópico-unitaria" (Báez I9I) y da paso a síntomas o "malestares" simultáneos que indudablemente suman al conjunto de formas en las que se configura la mirada. Es justamente bajo el imperio canónico, naturalista y preciso propuesto por el régimen visual dominante, al que Jay llama "perspectivismo cartesiano", que la tradición visual redujo al retrato a un criterio de semejanza con su modelo ${ }^{2}$.

En este mismo tenor, Javier Portús afirma que durante el Siglo de Oro el retrato de carácter religioso también se distinguió por su inextricable relación con la "viveza imitativa", sin embargo, el autor reconoce también que expresiones contenidas en crónicas en torno a la vida de los santos y venerables como "le pintó muy al vivo un artista" o "le copiaron muy al vivo" (Portús I74) trascienden la mera fórmula de caracterización naturalista, pues se refieren también a la eficacia utilitaria de la representación a partir del uso de un conjunto de convenciones iconográficas con aspiraciones arquetípicas codificadas. Lo anterior con el fin de facilitar una lectura más o menos universal de las imágenes y construir así una imagen de santidad mucho más concreta (Portús I72). Al respecto, Pierre Civil menciona que, si bien existió una amplia valoración de los retratos reales y fidedignos, las representaciones de los santos oscilaron entre la idealización de los personajes, con miras a inscribirlos dentro de un modelo de santidad determinado, y la veracidad de sus rasgos, con el fin de humanizarlos (350).

De este modo, la caracterización de la representación retratística en el contexto religioso presenta al menos dos problemas importantes: por un lado, se debate entre la veracidad y la idealización y, por otro lado, se vale de una serie de convenciones iconográficas y hagiográficas, con el fin de integrar una imagen homogénea de santidad. A dichos problemas habría que añadir el hecho de que estas imágenes poseen como sustento una serie de textos sagrados y edificantes, fundamentales al momento de difundir los modelos de virtud

2 Como ejemplo de ello, cabe revisar la definición de imagen planteada por el pintor y tratadista Antonio Palomino en el índice de términos de su Museo pictórico y escala óptica de 1715 : "Imagen, s, f. Semejanza puntual de alguna cosa corpórea" (Palomino 316 ). 
que habrían de instaurarse en el imaginario colectivo de la época ${ }^{3}$, razón por la cual su consulta es imprescindible al momento de construir aquella unidad simbólica a la que llamaremos "imagen de santidad", en un sentido más amplio.

Por todo lo anteriormente expuesto, una visión cerrada y centrada en una supuesta claridad y transparencia de la forma, resulta sumamente limitada para abordar el tema del retrato religioso en el contexto de los siglos XVII y XVIII, tanto en España como en la América colonial. En consecuencia, el retrato religioso, al igual que los problemas de los que se acompaña, hacen parte de un régimen escópico, paralelo y alternativo, al que Martin Jay ha denominado "barroco" (234), por situarse temporalmente en un momento y un conjunto de necesidades específicas ${ }^{4}$, no por un asunto de carácter estilístico. El autor apunta a que este régimen "posee una fascinación por la opacidad, la ilegibilidad y el carácter indescifrable de la realidad que pinta" (Jay 235), y dentro de esta lógica es natural que el retrato religioso revele su condición convencional antes que mimética y discursivamente clara; dichas convenciones son de naturaleza esencialmente teológico-hagiográfica y a su vez determinan el conjunto de modelos iconográficos e interpretativos que rigieron la composición y la lectura de la imagen retratística en cuestión.

\section{Las convenciones iconográficas y el problema de la veracidad y la verosimilitud}

En lo que respecta a los retratos inscritos en el contexto religioso, y concretamente las vera effigies pertenecientes al ámbito de las órdenes religiosas, son numerosos los textos que aseguran la existencia de un conjunto de convenciones iconográficas al servicio de la utilidad y la eficacia de la imagen en cuanto vehículo de comunicación de virtudes, actitudes y modos más o menos homogéneos de experimentar la fe y la religiosidad. Así pues, términos como "modelos", "patrones", "arquetipos", "códigos", "estándares", "coincidencias" o

3 El Santo Ecuménico Concilio de Trento le concedió un lugar imprescindible a la representación visual como vehículo esencial para la propagación de las virtudes cristianas: “Enseñen con esmero los Obispos que por medio de las historias de nuestra redención; expresadas en pinturas y otras copias, se instruye y confirma el pueblo recordándoles los artículos de la fe, y recapacitándoles continuamente en ellos..." (El sacrosanto y ecuménico Concilio de Trento 328-33I).

4 Jay ubica en este régimen a las imágenes religiosas producidas en el contexto contrarreformista y producidas hasta el siglo XviII. 
"convenciones" se encuentran reunidos en las investigaciones encargadas de dar cuenta del fenómeno del retrato religioso, con el fin de explicar la manera en la que este se constituyó formalmente y reunió una serie de rasgos y atributos susceptibles de ser identificados. En ese mismo tenor, Javier Portús se ha referido al proceso de formación de un vocabulario formal de carácter arquetípico y muy codificado que dio como resultado el que los retratos respondieran a patrones semejantes (I7I). Asimismo, menciona la preocupación por poner dichos estándares al servicio de la veracidad histórica del personaje en cuestión que, como se ha expuesto, encontró sustento en las fuentes sagradas, sus concordancias y, por supuesto, en los textos hagiográficos, al grado en que numerosos tratadistas de la época se inspiraron en ellos para crear sus modelos 5 . Por lo anterior, "pintar al vivo" y "verdaderamente" a un personaje, ya fuera vivo o muerto, implicó sujetarse a los testimonios escritos en torno a este, todo ello a favor del afianzamiento de la credibilidad de la imagen, pues no debe omitirse que su utilidad y su eficacia habrían de probarse en los momentos de lectura, recepción e identificación con la vida, obra y virtudes del personaje representado. Respecto al estatuto de la pintura religiosa en relación con su fidelidad mimética y su potencial edificante, Francisco Pacheco señala:

Y si el fin de la pintura (considerada solo como arte) decíamos que es asemejarse a la cosa que pretende imitar, con propiedad: ahora ańadimos, que ejercitándose como obra de verdadero Cristiano, adquiere otra más noble forma, y por ella pasa al orden supremo de las virtudes. [...] Así que hablado a nuestro propósito, la Pintura que tenía por fin solo el parecerse a lo imitado, ahora como acto de virtud toma nueva, y rica sobre este; y de más de asemejarse, se levanta a un fin supremo, mirando a la eterna gloria. [...] También vemos que las imágenes Cristianas no solo miran a Dios, mas a nosotros, y al prójimo. Porque no hay duda sino que todas las obras virtuosas pueden servir juntamente a la gloria de Dios, a nuestra enseñanza, y a la edificación del prójimo. (Pacheco I4O-I4I)

Pero ¿qué implican en teoría la veracidad y la verosimilitud?, ¿son en verdad lo mismo, tal como parece vislumbrarse en los estudios relativos al retrato religioso? María Ledesma menciona que "de la misma manera en que las

5 Portús menciona tratados de codificación iconográfica como los de Paleotti, Molano y Pacheco. 
convenciones de la época condicionan la representación icónica, las imágenes poseen un lugar activo en la conformación de una serie de conceptos, creencias e imaginarios" (2), por ello es que si un régimen escópico alude a la existencia de cierto modo dominante de ver en cada época, se considerará "verosímil” aquello que cada régimen habilite como tal. En estos mismos términos, es importante destacar lo expuesto por Christian Metz respecto a que lo verosímil es aquello que no está sometido a prohibición y por ende resulta razonable, convirtiéndose así en una poderosa censura respecto a lo que puede ser dicho o mostrado (Ledesma 4). En este sentido, verosímil y verdadero serán conceptos distintos o en ciertas ocasiones opuestos, ya que lo verosímil se encuentra determinado por el sentido común que se inscribe en este modo dominante de ver, y lo verdadero, en cambio, se refiere a lo fenoménicamente veraz, en alusión directa a los hechos reales.

Entonces, el ámbito de las "convenciones iconográficas” obedecerá a aquello que por acuerdo tácito se encuentre aprobado en términos de su coincidencia con las fuentes escritas encargadas de velar por la ortodoxia y la homogeneidad de las prácticas religiosas. Por ende, incluso aquellos testimonios que en su momento elogiaron la viveza imitativa o naturalista de los retratos religiosos con relación a su modelo real, lo hicieron en función de lo convencionalmente permitido. Asimismo, es posible que un retrato represente rasgos o actitudes veraces pero, al no ajustarse a las normas de representación, resulte carente de credibilidad o sin posibilidad de identificación y por ende poco icónico ${ }^{6}$. En este sentido, en el caso del retrato religioso, sus niveles de iconicidad, identificación y credibilidad, dependerán, tanto más de la representación de un conjunto determinado de atributos, rasgos y actitudes avalados por las fuentes escritas que de sus cualidades imitativas. Aunque esto no quiere decir que, en ciertos casos, la fidelidad mimética no sea importante e incluso determinante en términos de su utilidad y eficacia.

6 Roman Gubern, en su obra La mirada opulenta. Exploración de la iconósfera contemporánea, apela a los grados de iconicidad para describir la capacidad de una imagen de ser reconocida por un determinado grupo de individuos. Así pues, señala que la iconicidad será un factor cultural que puede medirse empíricamente tomando en consideración dos variables perfectamente cuantificables: el número de sujetos que identifica a una forma visual como una representación icónica determinada (factor al que denomina $N$ ) y el tiempo empleado en su identificación (factor $T$ ). Finalmente, concluye que en cuanto mayor es $N$ y menor es $T$, mayor será la tasa de iconicidad de la forma propuesta. 


\section{Tensiones entre codificación e individualidad: el retrato corporativo}

Es preciso distinguir entre aquellos retratos individuales, conocidos como retratos de aparato, y el retrato corporativo cuya función principal se centra en la representación de un individuo como miembro de un cuerpo social o colectivo determinado, con el fin de representarlo también. La historiadora del arte novohispano Paula Mues Orts asegura que en el retrato corporativo "se privilegió la generación del sentimiento de pertenencia, unidad y estabilidad, ante la personalidad individual de los miembros del cuerpo social" (89). Dicho cuerpo social se construyó a partir de una analogía normada y uniforme, encargada de proveer a la cabeza simbólica de la corporación de un carácter sólido, estable y continuo en su labor. Los retratos corporativos, en palabras de la autora, dieron cuenta de la historicidad institucional y asimismo otorgaron a los receptores una sensación de solidez, permanencia y distinción social, al momento de relacionar al personaje o personajes representados con la corporación a la que pertenecieron.

De acuerdo con lo anterior, es posible afirmar que en este tipo de representaciones existió una preferencia por los rasgos de identificación grupal o colectiva, incluso por encima de aquellos relativos a la individualidad del personaje, en términos de su fidelidad mimética. Esto no quiere decir que en muchos casos no se tratara de una imagen fidedigna, no obstante, fueron precisamente los atributos y los símbolos de pertenencia a un grupo determinado los que dotaron al retrato corporativo de verosimilitud y asimismo propiciaron en el espectador los sentimientos de aceptación e identificación respecto a este. En tal sentido, Paula Mues afirma que "el retrato no podía ser el resultado de la mera copia del natural, sino que era necesario atender a la categoría social del retratado y representarlo según su condición, dignidad o idea de sí mismo” (85). En lo relativo a la caracterización del retrato corporativo novohispano, la autora hace énfasis en la existencia de una dicotomía entre naturalismo e idealismo, con una fuerte tendencia hacia lo segundo. Por ello, en términos historiográficos, este género ha sido considerado en numerosos textos de arte novohispano secundario, por calificársele de "poco naturalista, y falto de originalidad en su composición y factura” (84). Debido a esto, según la autora, el retrato corporativo no ha recibido la atención requerida por parte de los especialistas, en relación con el conjunto de expectativas, valores y vínculos sociales generados alrededor de sus codificadas formulaciones. 
En términos de lo anteriormente expuesto, es importante señalar que existió, al menos en teoría, una diferencia entre pintar aequalitas, es decir, equiparando al modelo viviente, pintar similar o metafóricamente y, por último, formular una imagen o imago a partir de una serie de convenciones e incluso modificaciones en pro de una construcción de carácter esencialmente simbólico. En este sentido, Mues (86) apela a lo expuesto por el tratadista Gabriel Paleotti, quien distingue entre los conceptos de igualdad, semejanza e imagen, en relación con el tamaño de las obras, ya que si en realidad se buscaba generar la impresión de igualdad entre la pintura y su modelo, la representación debía realizarse del mismo tamaño que este, es decir, respetando en todo momento las proporciones naturales y tomando en cuenta su ubicación espacial. De lo contrario, la obra solo sería similar o metafórica:

una cosa es imagen, otra similitud, otra igualdad (semejanza) [...] [por lo que] en donde hay imagen se sigue similitud pero no se sigue igualdad; donde hay igualdad hay similitud pero no se sigue imagen, donde similitud no se sigue imagen y no se sigue igualdad.? (Paleotti i7)

En el retrato corporativo, la categoría con la que pudo haberse definido es la de imago, en cuanto imagen modificada que no poseyó la intención de sustituir al original aequalitas, sino la de conformar un cuerpo de identificación colectiva mediante el uso y la reiteración de una serie de motivos, atributos, actitudes, símbolos e incluso rasgos físicos, con el fin de comunicar una serie de valores grupales y sobre todo espirituales, en el caso de los retratos realizados en el contexto de las corporaciones religiosas.

\section{El papel de la codificación en la historiografía del retrato monjil novohispano}

Numerosos son los estudios que se han encargado de dar cuenta del retrato en el contexto monacal femenino novohispano, sin embargo, resulta esencial emprender una revisión de los criterios utilizados al momento de su análisis,

7 Aliud est imago, aliud aequalitas, aliud similitudo: ubi imago, ibi continuum similitudo, non continuum aequalitas; ubi aequalitas, continuum similitudo, non continuum imago; ubi similitudo non continuum imago, non continuum aequalitas. 
ya que en muchas ocasiones estos estudios suelen asentarse en el prejuicio de la "buena factura pictórica", ya sea en relación con el grado de fidelidad alcanzado con respecto a su modelo, o por sus cualidades de índole decorativa. Sin embargo, otro de los criterios en los que algunos de estos estudios han sentado sus bases es el de la codificación, en cuanto medio efectivo de comunicación de condiciones más profundas a partir del uso reiterado y homogéneo de ciertos elementos y actitudes dentro de los retratos. En este sentido, volviendo a la dialéctica entre naturalismo e idealismo que distingue al retrato corporativo, es posible observar en la historiografía del retrato monjil novohispano, la existencia de una tensión entre la representación de una personalidad de carácter individual y la manifestación de una presencia de carácter colectivo.

De acuerdo con lo anterior, es necesario volver la vista a las investigaciones más representativas en esta materia y el modo en el que han planteado dichas ambivalencias. En principio y en lo referente a la "calidad" de los retratos de monjas, es importante remontarse al primer estudio realizado por Josefina $\mathrm{Mu}$ riel y Manuel Romero de Terreros, titulado Retratos de monjas. Concretamente, en el capítulo IV, titulado "Los retratos que conocemos", la autora expone:

Los retratos de monjas que conocemos fueron hechos en una época en que la pintura mexicana se hallaba en decadencia. Verdad es que, a pesar de esto, encontramos obras pictóricas que conservan dignidad suficiente, pero realmente son las menos, y los pintores que se agrupan a su alrededor son, a pesar de la importancia que entonces tuvieron, figuras mediocres. (Muriel y Romero 35)

Los criterios de valoración anteriormente expuestos se fincan en dos aspectos en particular: por un lado, la fortuna crítico-historiográfica de la que gozaban los autores de estos retratos en el momento en que Josefina Muriel escribió su aportación y, por otro lado, el prejuicio historiográfico en torno al modo de pintar durante el siglo xviıI, al que no solo se refiere como decadente, sino de un barroquismo exacerbado y preocupado únicamente por la exaltación de la forma complicada (Muriel y Romero 37). De acuerdo con lo anterior, la autora suele reducir los retratos de monjas a una mera formulación decorativa:

Así mientras en casi todos los temas de la pintura de ese tiempo, las obras nos parecen falsas, alambicadas, carentes de ingenio e indignas [...], en los retratos de profesión de monjas no sucede lo mismo; porque estos no exigían la mente genial de un gran artista, solamente pedían 
decoración. Se necesitaban buenos dibujantes y éstos los había. La composición era siempre la misma, un fondo oscuro, sobre el que destaca la figura: una mujer ataviada con los arreos de un desposorio místico. (Muriel y Romero 36)

Muriel reduce el valor de las representaciones monjiles a un reclamo únicamente decorativo y, al mismo tiempo, a una mera y reiterativa serie de formulaciones iconográficas, sin indagar más en si estas poseían alguna utilidad. Por ello, en su opinión, no se requerían grandes maestros para llevarlas a cabo. Más adelante, la historiadora entra en profunda contradicción al asegurar que durante las ceremonias de desposorios místicos no había cosa alguna que careciera de amplio significado y por ende su representación debía "ir más allá” en términos de factura pictórica: "Estas pinturas exigen, más que ninguna otra, la mano de un artista, y siendo esta época, como ya lo hemos dicho, de decadencia pictórica, la mayoría de estos retratos son una mediocridad" (Muriel y Romero 45).

Sin embargo, la autora parece no ser la única en haber medido la calidad pictórica de estas representaciones en términos de la riqueza decorativa manifiesta en ellas. De igual manera, Rogelio Ruiz Gomar, en su aportación al catálogo Monjas coronadas de 1978, exalta particularmente los retratos de profesión, por ser los más profusos:

Dentro de las pinturas que se refieren a las monjas, sobresalen aquellas que se ocupan de dos de los más importantes momentos en la vida de un convento: la profesión y la muerte. Vengamos ahora a hablar un poco de los primeros que, por otra parte, son los más bellos. Como aluden al glorioso acontecimiento de los desposorios con Cristo, dependiendo de la orden [religiosa] a la que pertenecían, van ataviadas, en su gran mayoría, con espléndidas galas (Ruiz 39)

Uno de los estudios más exhaustivos en materia de este tipo de representaciones, titulado Monjas coronadas. Profesión y muerte en Hispanoamérica virreinal, de Alma Montero Alarcón, reconcilia la tradición historiográfica inclinada por la profusión decorativa, con la codificación esencialmente simbólica existente en muchos retratos de monjas, aduciendo que el ornato y el artificio de ninguna manera se contraponen a una visión trascendente y profunda de la vida conventual femenina. Sin embargo, la autora termina por reducir el problema 
de la codificación a un intento de simplificación de los mensajes contenidos en la representación, con el fin de facilitar su lectura. En este sentido, menciona que los retratos monjiles se encontraban dirigidos "a públicos devotos y sencillos" y que fue en función de su carácter "didáctico" que su factura pictórica podía calificarse de "ingenua", pues "buscaban transmitir mediante imágenes de sencilla lectura, los sentidos ejemplarizadores de algunas vidas virtuosas" (Montero, Monjas coronadas 3I).

En lo que respecta a la tensión existente entre la representación de una personalidad individual o una presencia de carácter colectivo, la historiografía suele conceder mucho más valor pictórico a aquellos retratos que manifiestan rasgos de individualidad, es decir, que ofrecen una impresión más "viva” y "natural” del personaje. Así lo manifiesta Alma Montero Alarcón:

Estas pinturas constituyen un testimonio histórico que confiere un carácter individual a los personajes retratados. En un claro intento por perpetuar su recuerdo más terrenal, los artistas del período virreinal realizaron retratos en toda la extensión de la palabra, los cuales tienen la característica de transmitir un gran humanismo ("Pinturas de monjas coronadas" 49)

Si se observan con detenimiento los retratos es posible percibir características distintas entre ellos a pesar de su gran similitud. (Monjas coronadas 229)

Creer que son "más retratos" aquellos que apuestan por la fidelidad de los rasgos del personaje representado no es extraño ni arbitrario si se toma en cuenta lo expuesto por Javier Portús respecto a que la eficacia utilitaria de la imagen era más, cuanto mayor relación tuviera con el modelo, y, en este sentido, la representación de los rasgos del rostro supuso en cierta medida una captura de la personalidad del individuo retratado (I73). En términos de dicha utilidad religiosa, Doris Bieñko de Peralta en su artículo dedicado a las Verae Effigies de los venerables angelopolitanos, sostiene que la intención de las imágenes al vivo era despertar la devoción y conmover al público, así como perpetuar la memoria del personaje. Para ejemplificar lo anterior, expone el caso de la invención prodigiosa del retrato de santa Gertrudis la Magna, mandado hacer por fray Diego Yepes y para el que se tomó como modelo a una religiosa benedictina anónima: 
La diferencia entre el original y la copia consistió, en palabras del obispo, en que la segunda fue más perfecta, pues el pintor al hacer su trabajo le confesó que "con ser muy puntual en trasladar otras imágenes muy al vivo, en ésta no pudo atinar al original, sino que cuantas veces ponía el pincel, sacaba las facciones mejor de [lo] que él pensaba ni imaginaba". (Bieñko 258)

La cita anterior permite comprender mejor la singular relación del retrato religioso femenino con su modelo, pues en este caso fue por medio del prodigio que el pintor se acercó cada vez más a la imagen verdadera de la santa. Sin embargo, no hay que perder de vista que el artífice se inspiró inicialmente en la representación de otra religiosa de la misma orden. Esto nos conduce a afirmar que la particularidad manifiesta en los rasgos de cualquier personaje debía asentarse también en la generalidad, es decir, tomando como base un conjunto de motivos iconográficos y actitudes convencionalmente descriptivas, con el fin de contribuir a la verosimilitud de la imagen, su aceptación y su eficacia comunicativa. No debe olvidarse que, finalmente, se trataba de posibilitar una lectura más o menos universal de estos retratos con el propósito de difundir el conocimiento en torno a figuras dignas de ser imitadas.

Aunque es verdad que tanto la finalidad retentiva como la posible función sustitutoria, e incluso la intención humanizante de estos retratos, influyeron para que su valoración se planteara, al menos historiográficamente, en términos de su cercanía con el modelo vivo, es precisamente en su carácter convencional, arquetípico e incluso reiterativo, relacionado por numerosos autores con cierta "precariedad estilística", que radica el potencial icónico que los consolida como "retratos corporativos" y, de manera específica, como "retratos monacales", en cuanto albergan el espíritu de la vida conventual y la esencia de sus carismas particulares, todo esto con el fin de establecer lazos de identificación y estimular la memoria colectiva en el interior y en el exterior de los conventos.

De acuerdo con el momento de la vida de la religiosa en que se le haya representado, estos retratos plantean diversos problemas, ya que obedecen a situaciones diferenciadas y por ende ostentan atributos y actitudes distintas. En este sentido, diferentes serán también sus niveles de lectura. Por último es importante considerar la naturaleza de la observancia regular de la corporación $\mathrm{u}$ orden religiosa de la que se trate, pues ello influyó de manera sustancial en el modo en el que se retrató a las religiosas. 


\section{Profesión, muerte y homenaje: tres momentos, tres retratos}

\section{Los retratos de profesión}

El momento más afortunado de la vida de una monja, en cuanto al número de representaciones pictóricas existentes hasta nuestros días, es sin duda el de la profesión o desposorio místico con Jesucristo. Aunque existen otros retratos estrechamente relacionados con este momento, como aquellos anteriores a la toma de estado religioso y otros más en los que se representa a las religiosas como novicias, son sin duda los de profesión los más popularizados, al ser patrocinados casi sin excepción por los parientes y los padrinos de las futuras monjas, incentivando con ello su cuantiosa producción. Estos poseían como cometido principal, la preservación y exaltación de la memoria en torno a la hija que habría de salir del seno familiar para formar parte de una corporación religiosa y a dedicarse en cuerpo y alma al cultivo de la virtud y la aspiración a la santidad. Por estas razones, la elaboración de retratos fue una constante en las singulares empresas de familias, padrinos y benefactores involucrados en las ceremonias de desposorios místicos.

Aunque es verdad que la corona, la palma, el cirio, los escudos, los crucifijos y las figuras de niños Dios son atributos que distinguen a innumerables retratos de profesión, es necesario señalar que su formulación y presencia no obedecen a una moda, ni mucho menos a razones de índole decorativa, como algunos autores suelen sugerir a lo largo de la historiografía del arte novohispano. Es probable que el modo en el que dichos atributos fueron solucionados plásticamente haya sido influido por ciertas tendencias pictóricas, sin embargo, no hay que olvidar que tanto las fuentes escritas como los modelos visuales derivados de ellas fueron las directrices más importantes al momento de formular el conjunto de convenciones que distinguieron a los retratos de profesión. Es preciso aclarar que no todos estos retratos tuvieron como imperativo la fastuosidad, ni todos llegaron a convertirse en símbolos de estatus social; aunque es verdad que, al no ser encargados por los propios conventos, ni estar destinados a permanecer en ellos, puede percibirse cierta libertad en la forma y la profusión con la cual tanto hábitos como atributos fueron representados.

Lo que es un hecho, es que los elementos característicos de estos retratos son de una profunda y compleja significación simbólica. Así lo manifiesta la 
propia Asunción Lavrin: "El significado de la riqueza y los aderezos personales que [la religiosa] portaba es complejo. Si bien los símbolos religiosos eran adecuados para la ocasión, podían hablar también sobre la vanidad del mundo que dejaban atrás" (89). Por su parte, Sergi Doménech (3) asegura que la iconografía de los retratos de profesión representa un despliegue visual de la liturgia de consagración de las vírgenes, y, en ese mismo tenor, Alma Montero Alarcón añade que los atributos de los que se compusieron, como coronas, cirios, palmas floridas y vegetales, así como crucifijos, esculturas de niños Dios y escudos, fincaron sus propósitos simbólicos en esa y otras fuentes litúrgicas, por lo que los pintores exaltaron su estatuto mediante la decoración. Del mismo modo, otros elementos, como accesorios, joyas y brocados se sumaron a dichas intenciones con el fin de revestir a la monja de significación:

Como se ha mencionado, el engalanar a las religiosas, cubrirlas de flores y en ocasiones de joyas, guardaba diversos significados que trascendían el simple ornato, y los elementos iconográficos que portaban tenían un claro sentido litúrgico. Entre estos elementos destacan sin duda la corona y la palma como dos símbolos fundamentales que llevaban las monjas en los momentos más sobresalientes de su vida religiosa. (Montero, Monjas coronadas 179 )

El primer atributo que es preciso ubicar en los retratos de profesión, siguiendo el orden usual de las ceremonias de desposorios místicos, es la vela. Esta no solo simboliza la luz de la fe, sino que ciertamente es el despliegue material de un momento litúrgico específico: aquel en el que el sacerdote lee a la novicia un fragmento de la parábola de las vírgenes, contenida en el evangelio de Mateo: "Vírgenes prudentes, preparad vuestras lámparas, he aquí que viene el Esposo, salidle al encuentro" (Doménech, I). Tanto Sergi Doménech como Alma Montero coinciden en que la presencia del cirio, en relación con la parábola, alude a que la monja pertenece al grupo de las vírgenes prudentes, pues se encuentra internamente preparada y con su lámpara encendida a la espera de su encuentro con el esposo divino.

La corona es un elemento que se asocia en un principio con la victoria, puesto que el asumir los votos perpetuos implicó la renuncia al mundo material y la entrada a un universo consagrado a la edificación espiritual. Esto supuso en la vida de la monja un primer triunfo en el camino de aspiración a la santidad, pues el desprecio del mundo es uno de los requisitos fundamentales para el logro de dicho cometido. Del mismo modo, el momento de la profesión adquiere una 
dimensión triunfal si se toman en cuenta las múltiples vicisitudes que una aspirante a monja debía librar, las cuales incluían el cumplimiento de innumerables requisitos personales y económicos para su ingreso al convento, el noviciado e incluso el voto final de aceptación por parte de la comunidad de religiosas.

Alma Montero asegura que en la iconografía cristiana, la corona, además de simbolizar la victoria, representa también "la felicidad eterna reservada a las muertes justas" (Monjas coronadas I79). Lo anterior conlleva una profunda significación si se toma en cuenta que en la vida de una religiosa, la corona le era impuesta por primera vez al momento de asumir de manera definitiva e irrenunciable los votos perpetuos durante la ceremonia de profesión, en la que por supuesto moría para el mundo. Ya fuera como esposa o como vencedora, no cabe duda de que la corona es un símbolo que asocia directamente a la monja con Jesucristo, sin embargo, tomando en cuenta lo expresado por Sergi Doménech en cuanto a que todos estos atributos se encuentran relacionados con la liturgia de consagración de las vírgenes, es preciso apuntar a que su representación se encuentra también asociada al triunfo y las virtudes de la Virgen María. De hecho, es importante precisar que el simbolismo de la corona, en términos marianos, se relacionó también con la devoción al rosario, el cual se rezaba de diferentes maneras hacia mediados del siglo xv, a partir de distintas simbologías numéricas. Según la tradición dominica, se rezaba a modo de corona de rosas (compuesta por siete misterios asociados a los 63 años de vida de la virgen), y de acuerdo con la tradición inmaculista franciscana se rezaba a modo de corona de doce estrellas o stellarium (compuesto de doce meditaciones en torno a los privilegios de María). De esta manera, se sabe que las coronas meditativas en torno a la virgen, como es el caso del Libellus de Corona Virginis (siglos XII-XIII) u otras más tardías como el Aurea corona beatissimae Virginis Mariae (siglo xv), evocaron un conjunto de virtudes marianas específicas a través de su vinculación metafórica con las propiedades de ciertas piedras preciosas, flores y cuerpos celestes. Finalmente, es importante añadir que la corona alude por supuesto al estatuto de María como reina del cielo y por ello se le representa en innumerables ocasiones portando la corona imperial.

No es casual que, por imitación de las virtudes marianas, numerosas santas porten también como atributo la corona floral, en alusión a la victoria, la felicidad, el amor y la pureza. Sin embargo, es importante señalar que existen representaciones en las que también aparecen con coronas vegetales, aludiendo al triunfo, el martirio y la humildad. Estas generalmente se componen de hojas de laurel o de olivo, según la tradición grecolatina que asocia a las primeras 
con la inmortalidad y a las segundas con la paz, la sabiduría y la prosperidad (Monterrosa 63). En el caso de las coronas florales, presentes en numerosos retratos de profesión novohispanos, fueron las rosas las flores preferidas para la elaboración y la representación de este atributo. Además de aludir al amor divino, el matrimonio y la sangre de cristo, las rosas se encuentran íntimamente relacionadas con la iconografía de santa Rosa de Lima, modelo en el que habrían de inspirarse numerosas corporaciones femeninas en América y a quien la mayoría de las veces se le representa coronada de rosas, en alusión al episodio de su desposorio místico con Jesús niño. Con respecto al impacto de la imagen de la santa limeña en gran cantidad de retratos de monjas, Ramón Mujica apunta lo siguiente:

No sería de extrañar, aunque es un tema abierto a la investigación, que los retratos moralizadores novohispanos de monjas coronadas de rosas y flores, simbólicos de sus esponsales con Cristo, estén vinculados con la ascética nupcial popularizada por la santa limeña [...] (95)

Finalmente, es posible advertir la existencia de una dialéctica estéticosimbólica en las coronas monjiles ya que, por un lado, su profusión física y pictórica resulta muy atractiva a los sentidos por su variedad floral, colorido y multiplicidad de materiales reales o emulados. Sin embargo, por otro lado, dicha fastuosidad se encuentra relacionada con la exaltación del estatuto de la monja como esposa del altísimo y por ende supone también, en términos simbólicos, la renuncia total a las vanidades mundanas, para dedicarse en cuerpo y alma a una vida de contemplación y ascetismo.

Otro de los elementos más importantes en los retratos de profesión es la palma, que al igual que la corona puede ser florida o vegetal y es posible apreciarla en numerosas representaciones pictóricas fusionada con la vela o cirio, formando un mismo atributo. Alma Montero asegura que el simbolismo de la palma suele encontrarse relacionado con al menos dos acepciones, ya que entre los romanos era símbolo de victoria, significado que conservó en el contexto cristiano y se trasladó a los mártires que perecieron en defensa de la fe (Monjas coronadas I8I). De igual manera, según Montero, este atributo puede aludir al momento en que Jesucristo entró a Jerusalén donde, triunfante, fue recibido con palmas. En este sentido y en lo relativo a la vida conventual, ya sea por vencer al mundo y al pecado o por aludir al sacrificio que habrán de representar las tribulaciones y las mortificaciones propias de la vida ascética, el significado de la palma se encuentra circunscrito al triunfo. 
Por otra parte, puede advertirse en numerosos retratos la presencia de medallones o escudos, generalmente utilizados en la Nueva España por las monjas concepcionistas y jerónimas ${ }^{8}$, prendidos del escapulario a la altura del pecho. En ellos pueden verse representadas escenas de la vida de la virgen como la anunciación y la asunción, o los santos venerados por la orden religiosa a la que pertenecía la monja. Es importante resaltar que muchos de estos medallones, originalmente pintados sobre lámina de cobre y montados en plata, nácar o carey (Muriel y Romero 25, 203), hoy se conservan en colecciones públicas y privadas e incluso están firmados por pintores notables de la época ${ }^{9}$. Del mismo modo, ciertas corporaciones monjiles, en su mayoría calzadas o urbanistas, suelen verse representadas portando una pequeña escultura de bulto del Niño Jesús ataviada de manera profusa y esmerada. La elaboración de dichas esculturas fue, por lo general, en madera tallada y policromada y en la actualidad son conocidas también como "divinos espositos". Se sabe por los ceremoniales de profesión que formaban parte de este ritual, sumadas a otros atributos como el cirio, la palma y la corona. Por el hecho de que algunas de estas esculturas aún se conservan en las colecciones de numerosos conventos, y por testimonios documentales, es posible saber que las religiosas los recibían de manos de sus familiares o padrinos con el fin de preservarlas por el resto de sus días en el monasterio. Traer a la memoria la imagen de Jesús niño mediante su representación escultórica, despertaba en las monjas sentimientos de ternura y devoción parecidos a los de una madre que además de dirigirle sus oraciones y meditaciones, dedicaría parte de su tiempo a bordar diligentemente sus ajuares. Asimismo, es importante señalar que la presencia del Nińo Jesús como pequeño esposo, de nueva cuenta alude a los pasajes de las vidas de santa Rosa de Lima, santa Catalina de Siena y santa Inés de Montepulciano, en los que fueron desposadas por él (figuras I y 2).

8 Entre los retratos en los que es posible identificar este atributo, se encuentran los de monjas concepcionistas, así como aquellos pertenecientes a conventos que la historiografía suele denominar "filiales" de la Concepción. Es el caso de los monasterios de Regina Coeli, Jesús María, Balvanera, La Encarnación, Santa Inés, San José de Gracia; asimismo en los conventos de San Jerónimo de México y Puebla.

9 Es el caso de los pintores Miguel Cabrera, Juan Patricio Morlete Ruiz, José de Alcíbar, Andrés López y Antonio Vallejo, entre otros. 


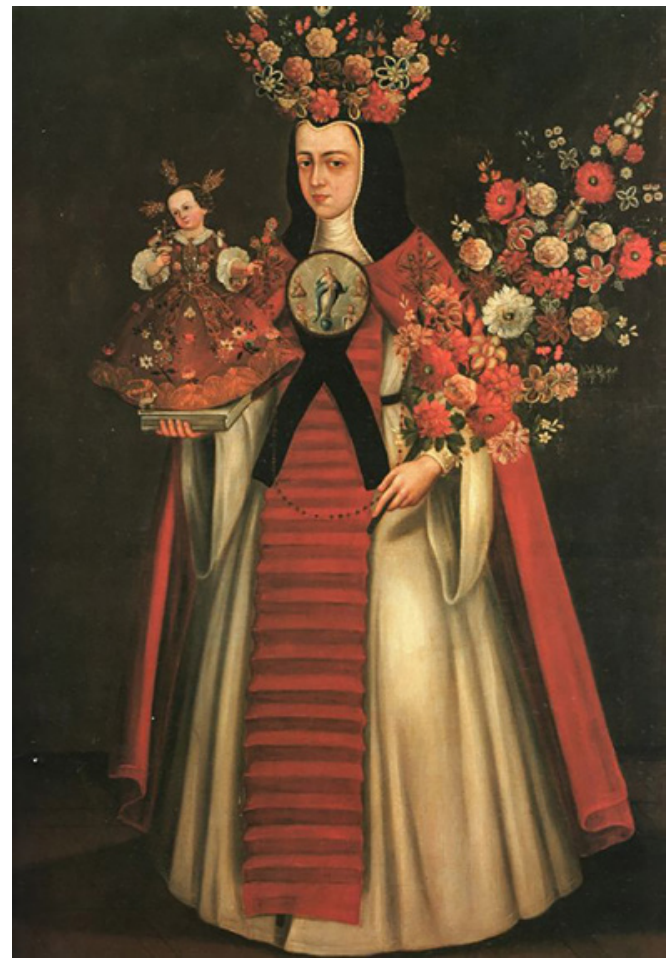

$\rightarrow$ FIGURA I.

Retrato de María Francisca Josefa de San Felipe Neri

Fuente: Anónimo, siglo xviı. Óleo sobre tela. Colección Museo Nacional de Historia. Instituto Nacional de Antropología e Historia, México.

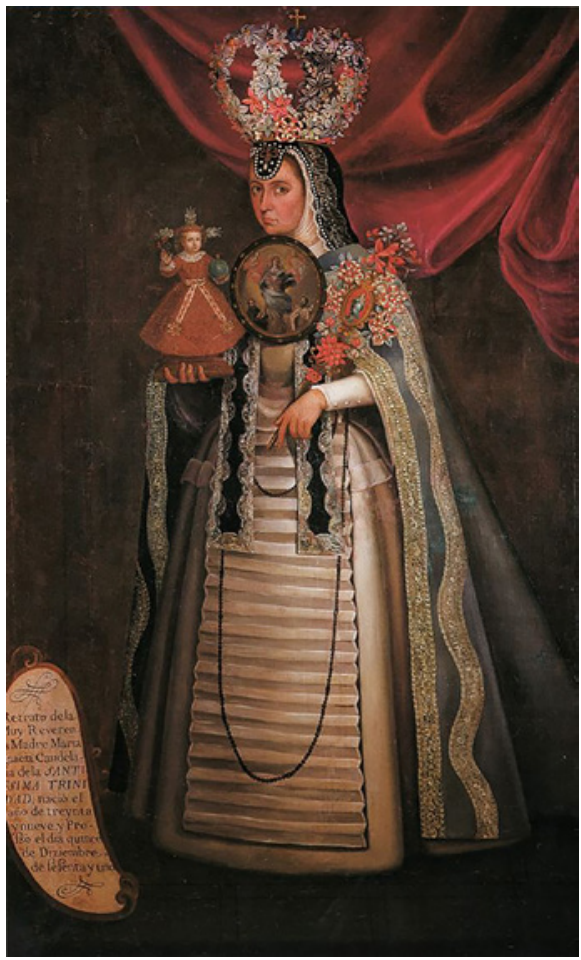

$\leftrightarrow$ FIGURA 2.

Retrato de sor María Ignacia Candelaria de la Santísima Trinidad

Fuente: Anónimo, siglo xviı. Óleo sobre tela. Colección Museo Nacional del Virreinato. Instituto Nacional de Antropología e Historia, México.

En lo relativo al criterio de similitud con su modelo, así como a la identidad individual de las monjas retratadas, las representaciones de profesión poseen una serie de variaciones determinadas tanto por la voluntad de quienes las encargaron, como por la destreza de los pintores a quienes fueron solicitadas. No obstante, el factor de mayor incidencia en ambos criterios es sin lugar a dudas el carisma espiritual de la orden a la que dichas monjas pertenecieron. En este sentido, es posible identificar la existencia de una tensión entre la presencia individual y la grupal, pues es verdad que en muchos de estos retratos se enfatizan los rasgos físicos de la religiosa en cuestión, tomando como eje el criterio de semejanza, que aunado a la cartela, donde se asienta información personal, como el nombre de la retratada, el de sus padres, lugar y año de nacimiento, la 


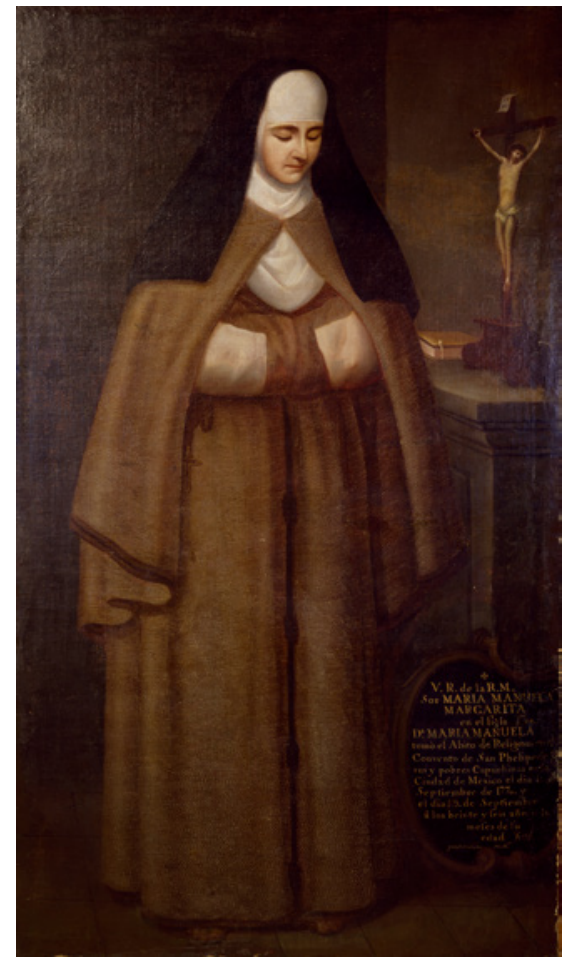

$\leftrightarrow$ FIGURA 3 .

Retrato de sor María Manuela Margarita

Fuente: José de Alcíbar, ca. I770. Óleo sobre tela. Colección Museo Soumaya.

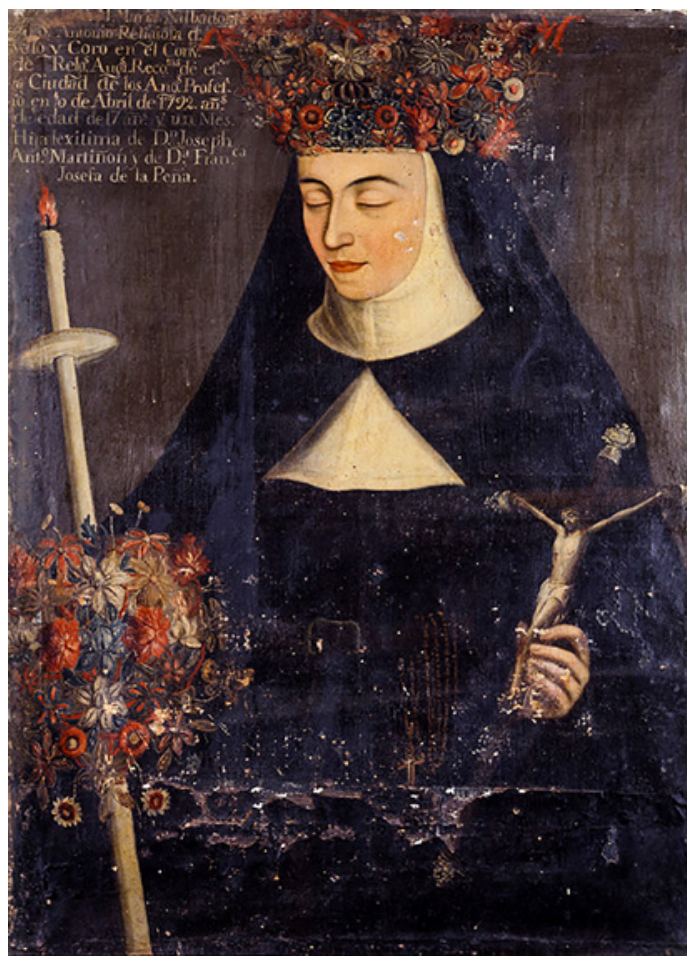

$\rightarrow$ FIGURA 4 .

Retrato de sor María Salvadora de San Antonio

Fuente: Anónimo. Siglo XVIII (I792). Óleo sobre tela. Colección Museo Nacional del Virreinato. Instituto Nacional de Antropología e Historia, México.

fecha de su ingreso al convento, el nombre de este y la orden religiosa en la que se inscribió, es claro que existe una exaltación de la identidad individual del personaje. Sin embargo, un buen número de retratos de profesión novohispanos carecen de cartela y aun teniéndola privilegian los rasgos de identificación colectiva, con el fin de promover el sentido de pertenencia a determinada corporación religiosa, así como el cultivo de virtudes específicas como la austeridad, la humildad y el recogimiento. Estas cuestiones habrán de superponerse, en términos iconográficos y simbólicos, a los rasgos individuales del personaje, favoreciendo la representación de gestos, ademanes, atributos y vestimentas de carácter convencional y estandarizado. En este sentido, gestualidades codificadas como la mirada baja o los brazos entrecruzados, elementos como crucifijos, 
breviarios o cilicios, atributos como palmas, cirios o coronas, representados de manera más sencilla y homogénea, habrán de caracterizar en su mayoría a los retratos de profesión de órdenes de naturaleza recoleta o descalza (figuras 3 y 4 ). Con base en lo anteriormente expuesto, resulta imprescindible contemplar la naturaleza de los distintos carismas espirituales al momento de analizar este tipo de representaciones, con el fin de propiciar estudios más profundos y focalizados e intentar trascender aquellos lugares comunes de la historiografía del arte novohispano que suelen atribuir la presencia y la solución formal de ciertos motivos y elementos iconográficos únicamente a la destreza pictórica, la moda o el gusto de la época.

\section{Los retratos de muerte}

El momento más importante y ańorado en la vida de una religiosa era sin duda aquel que representaba la consumación espiritual de sus desposorios místicos, es decir, la muerte terrena que habría de derivar en su encuentro final con Jesucristo. En este sentido, es necesario recordar que, si bien la profesión ciertamente suponía un matrimonio real, la relación terrena entre la monja y su esposo divino era susceptible de tornarse distante en ciertas etapas de la vida mundana, así como propensa a transitar por una serie de vicisitudes y tribulaciones. Por ello, a partir de la esperanza en la promesa de pasar de esta vida al goce eterno de la compañía de su dulcísimo esposo, las monjas padecieron con firmeza aquellos obstáculos. Aunque las honras fúnebres poseen variaciones protocolarias, según las constituciones y los ceremoniales de cada orden religiosa, en todos los funerales se procedía a amortajar el cuerpo de la hermana en cuestión y vestirla con el hábito de la corporación. Cabe señalar que si la religiosa había muerto de alguna enfermedad contagiosa, se le velaba y se le enterraba prontamente; en cambio, si la monja moría en otras condiciones, la ceremonia duraba un día; pero si se trataba de una priora o de una monja notable, las honras fúnebres podían extenderse hasta por tres días.

Portar de nueva cuenta, al momento de la muerte, la corona y la palma floridas únicamente podía significar "el triunfo de la muerte que solo otorga el llevar sin descanso ni tregua los votos religiosos" (Montero, Monjas coronadas I37-I38). Así pues, tanto la corona como la palma habrían de integrarse de nuevo para dar cuenta del virtuosismo con el que la hermana difunta había observado dichos votos, así como la regla y las constituciones de su sacro instituto. 
En este sentido, testimonios documentales como la vida de la religiosa dominica María Ana Águeda de San Ignacio, fundadora del Convento de Santa Rosa de la ciudad de Puebla, escrita por el jesuita Joseph Bellido, revelan la presencia de estos atributos durante las honras fúnebres:

Estaba el Cuerpo expuesto delante de la reja del Coro bajo, adornado con bellísima Palma, y Corona, como que supo triunfar, y salir victoriosa, como piadosamente creemos, de los más tiranos enemigos: estaba con variedad de hermosísimas flores, que abundantemente enviaron los Conventos de Recoletas, y muchas Personas Seculares [...] (Bellido I45-I46)

Tanto Josefina Muriel como Asunción Lavrin y Alma Montero coinciden en que las ceremonias fúnebres a mediados del siglo Xvir y a lo largo del siglo XVIII, llegaron a representar verdaderos actos públicos que lograban reunir a una muestra significativa de todos los estratos de la sociedad virreinal. A todo este "aparato" o énfasis en el aspecto ritual de la ceremonia, se sumó la imperiosa necesidad de contar con un testimonio visual de la monja en su lecho de muerte, sin embargo, es sabido que este fue un privilegio reservado a las monjas notables, ya que el derecho a la representación le era otorgado únicamente a las monjas fundadoras, a las preladas y aquellas religiosas que se hubiesen distinguido por la ejemplaridad de sus vidas. Tomando en cuenta que los retratos de muerte fueron solicitados en su totalidad por las propias corporaciones monjiles para fungir como dispositivos donde debía reconocerse la comunidad y reflejar las virtudes que había que imitar, este conjunto de representaciones posee en realidad intenciones de carácter edificante y comunitario, más que individualizantes.

Sin embargo, no hay que olvidar que muchas veces el retrato de muerte participó de algunas de las características que definieron a las reliquias, como la función sustitutoria, que según Javier Portús se producía en varios niveles (175). El más profundo de ellos consistía en una transmisión de los poderes devocionales o taumatúrgicos ligados al "original", que en este caso sería el cuerpo de la propia religiosa en su lecho de muerte. En este sentido, por medio de la contemplación del retrato, las monjas podrían no solo consolarse por la falta física de su compañera y asimismo evocar sus cualidades personales y espirituales, sino además reactivar el contacto con ella. Numerosas visiones post mortem registradas en textos hagiográficos confirman que, en efecto, las monjas vivas continuaban produciendo imágenes mentales y narrativas en relación con la monja perecida y, de este modo, seguían estrechando lazos afectivos con ella 
e incluso les eran concedidos algunos prodigios. Todo esto puede darnos una idea de la importancia de la representación visual para propiciar otro tipo de visiones y experiencias.

Con respecto a la construcción icónica de las monjas muertas, es preciso hacer énfasis en la existencia de dos tipos de representaciones. Por un lado, aquellas en las cuales las religiosas ostentan la apariencia de un cadáver y aquellas en las que aun muertas conservan un aspecto juvenil y vívido. En el caso de las primeras (figura 5), es necesario tomar en cuenta que tanto los padecimientos físicos derivados de los ayunos y las penitencias como las enfermedades comunes, e incluso las graves, se consideraban un ejemplo de paciencia cristiana y fortaleza espiritual. Por ello, la impronta de este conjunto de males no era para nada denostada al momento de enfatizarlos en los retratos fúnebres, puesto que la vejez, el dolor y la enfermedad eran vistos como obstáculos a los que estas monjas se habían enfrentado diligentes. De esta manera, mediante su representación, se enseñaba a la comunidad de monjas el arte del bien morir, reconociendo en las dolencias y miserias físicas de sus hermanas perecidas, la ruta de la perfección espiritual:

se trataba más bien de resaltar el elemento espiritual de la enfermedad como fuente de un sufrimiento deseable, que adquiría relevancia en la construcción icónica de monjas enfermas y en el sufrimiento como ejemplos imitables. [...] Es así como se reduce el cuerpo a un catálogo de sorprendentes imágenes evocadoras de descomposición que deben haber conmovido hasta las lágrimas o el temor. Esa era precisamente su intención. (Lavrin 243-245)

Existe otro tipo de retratos de muerte que distan mucho de ofrecer el patetismo propio de una monja difunta. Se trata de representaciones visuales de religiosas fallecidas en eminente olor de santidad, cuyos rasgos no solo se representan incorruptos, sino rejuvenecidos e incluso rozagantes. Como ejemplo de lo anterior puede citarse una de las múltiples representaciones pictóricas de la religiosa agustina poblana sor María de San José (figura 6) que, aun cuando fue realizada años después de su fallecimiento, tiene la intención de mostrarla con la expresión que conservó al momento de su muerte. Así lo afirma su cartela: "murió con el semblante que representa", es decir, apacible y juvenil, a pesar de rebasar los sesenta ańos. Aun cuando no se conservan retratos de todas las religiosas que fueron beneficiarias de dicho prodigio, se cuenta con sus biografías, escritas mayoritariamente por sus confesores. Es el caso de monjas novohispanas 


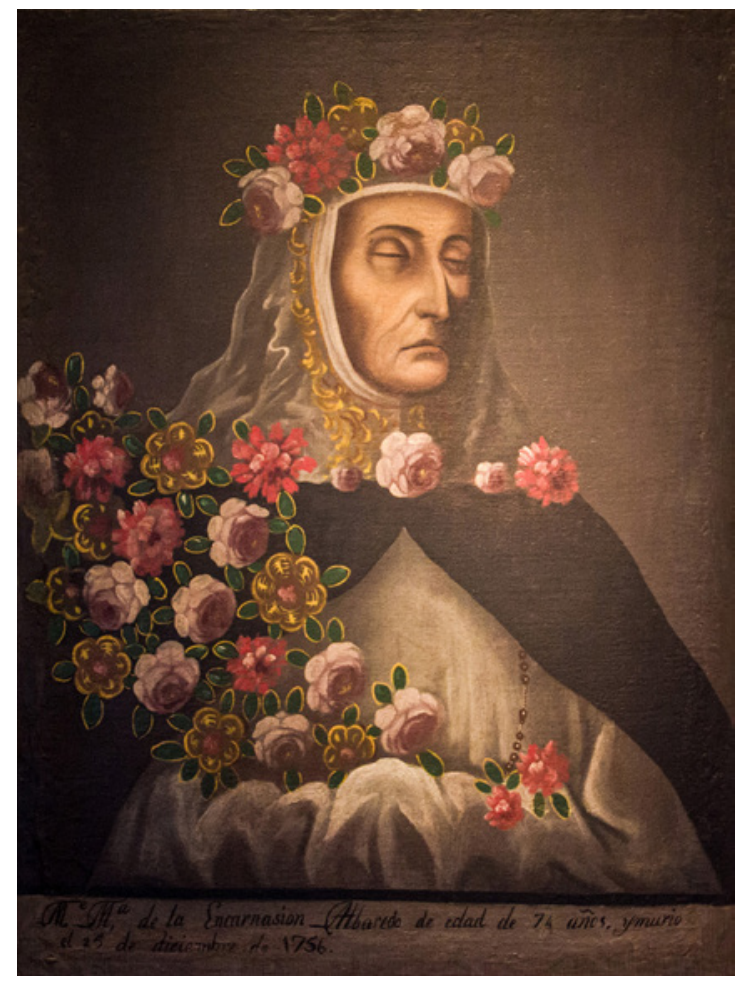

a FIGURA 5 .

Sor María de la

Encarnación Albaredo

Fuente: Anónimo, siglo xviII.

Óleo sobre tela. Colección: Museo de Arte Religioso, ex-Convento de Santa Mónica. Instituto Nacional de Antropología e Historia, México.

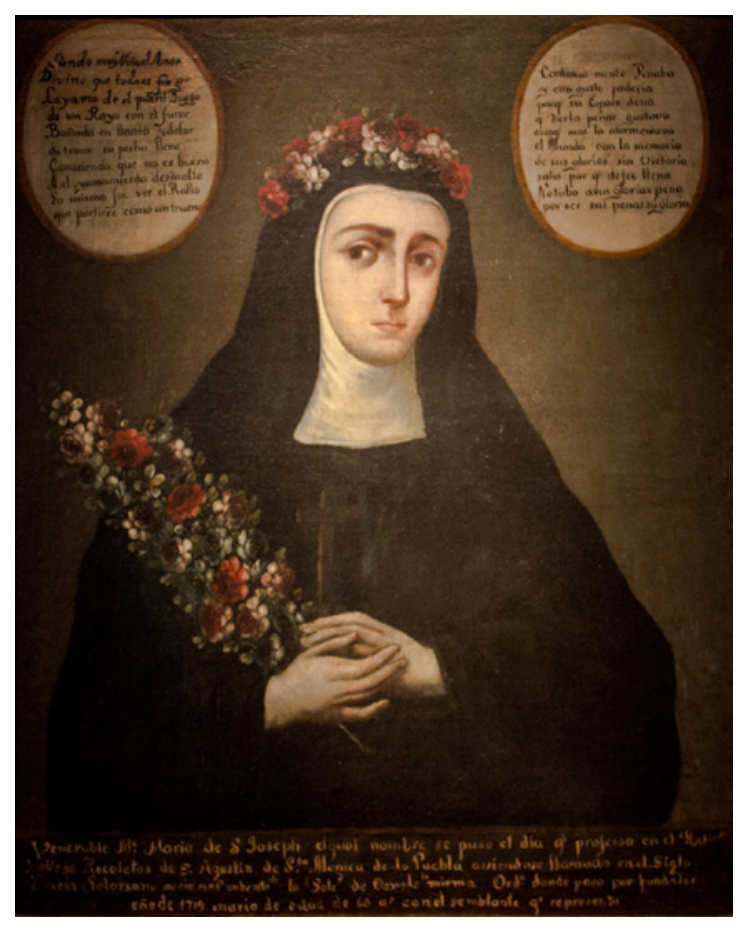

$\rightarrow$ FIGURA 6.

Sor María de San José

Fuente: Anónimo, siglo xviII.

Óleo sobre tela. Colección Museo de Arte Religioso, ex-Convento de Santa Mónica. Instituto Nacional de Antropología e Historia, México.

$\begin{array}{llllllllllllllllllll}\text { F } & \text { R O } & \text { N } & \text { T } & \text { E } & \text { R A A S } & \text { de } & \text { la } & \text { H I } & \text { S } & \text { T } & \text { O } & \text { R } & \text { I } & \text { A }\end{array}$ 
como sor Ana de Jesús, fundadora y primera priora del convento de carmelitas de San José de Puebla, o la religiosa agustina fundadora del convento de Santa Mónica de Puebla y de la Soledad de Antequera, sor Antonia de la Madre de Dios. Asimismo, en otras latitudes americanas, es posible identificar casos como el de la madre Ana de los Ángeles de Monteagudo en Arequipa, Perú, o la madre Mariana de Jesús Paredes y Flores, mejor conocida como la Azucena de Quito, entre muchos otros. Con respecto a estos acontecimientos Asunción Lavrin menciona lo siguiente:

La muerte rejuvenecía porque las virtudes de la vida religiosa se expresaban a través del cuerpo una vez que éste dejaba de ser la prisión del espíritu y podía manifestarse sin impedimentos. La gracia de Dios se manifestaba en ese proceso. (267)

Es importante mencionar que, además de la apariencia de la monja fallecida, existe otro elemento capaz de ofrecer información en torno a su estatuto al momento de morir. Se trata de las cartelas, en la que muchas veces se asienta el prodigio de la incorrupción de los cadáveres de estas virtuosas mujeres. Por último, resulta esencial ubicar espacialmente estos retratos de acuerdo con su función edificante en términos corporativos, pues es verdad que juntos conformaban una especie de cuadro de honor comunitario. En este sentido, es muy probable que dichas representaciones se exhibieran en lugares destinados al encuentro y la reflexión colectiva dentro del convento, como es el caso de los corredores de los claustros, los coros, la sala capitular o el despacho de la madre abadesa.

\section{Los retratos de homenaje}

Al igual que la profesión y la muerte, hubo otros momentos de suma importancia en la vida de las religiosas en los que también solía coronárseles e imponérseles la palma florida y la vela y asimismo representarlas pictóricamente. Es el caso de los aniversarios de bodas místicas, los nombramientos como abadesas e incluso otros acontecimientos post mortem ligados a causas de promoción de monjas notables. Cabe resaltar que dichas causas de promoción incentivaron la producción de nuevas representaciones con el fin de exaltar y promover la imagen de estas monjas ejemplares a ojos de quienes, o bien ya las conocían, o habrían por ello de conocerlas. A esto habrá que sumar también el 


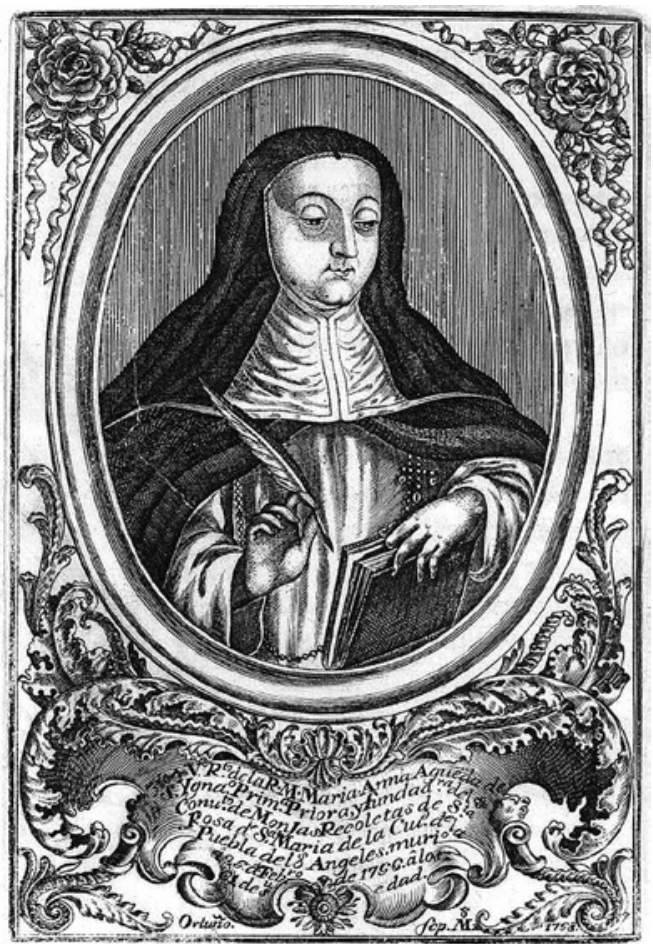

$\leftrightarrow$ FIGURA 7 .

Verdadero retrato de la reverenda madre Anna Agueda de San Ignacio

Fuente: José Benito Ortuño, siglo XVIII. Grabado. Biblioteca Nacional de México, UNAM.

conjunto de representaciones grabadas contenidas en numerosas ediciones de las vidas ${ }^{\mathrm{IO}}$ y escritos relacionados con estos personajes ejemplares. Es el caso de los retratos de las monjas sor Isabel de la Encarnación, sor María de Jesús Tomelín, sor María de San José y sor Anna Águeda de San Ignacio (figura 7) en la ciudad de Puebla ${ }^{\mathrm{II}}$, entre otros.

Io Podría decirse que hacia el siglo Xvir la biografía autorizada o vida obedeció a un modelo retórico más o menos homogéneo que acogió la serie de influencias discursivas que las monjas dejaron asentadas en numerosos manuscritos confesionales. Dichas influencias provienen, en su mayoría, de las lecturas devocionales y hagiográficas a las que eran asiduas. Así fue como confesores de sumo renombre, en su mayoría miembros de las órdenes religiosas, se dieron a la tarea de dar forma al conjunto de relatos escritos que sus religiosas dirigidas les cedían. Con esos materiales, afirma Antonio Rubial, "considerados como escritura de segunda, el autor masculino armaba una historia moralizante sobre las experiencias femeninas, las mediatizaba para volverlas 'legibles' y hacía público lo que se había mantenido en secreto" (Rubial I69).

II Véase Pedro Salmerón, Vida de la Vble. Madre Isabel de la Encarnación, México: 1675; Diego de Lemus, Vida, virtudes, trabajos, favores, y milagros de la Ven. M. Sor Maria de Jesús Angelopolitana, México: 1683; Sebastián de Santander, Vida de la Venerable Maria de San Joseph, México: 1723; José Bellido, Vida de la V.M.R.M. María Anna Águeda de S. Ignacio, México: 1758. 
En lo que respecta a este conjunto de representaciones, será preciso analizarlo desde ópticas diferenciadas y puestas en relación con la especificidad de cada caso, pues es común encontrar que en numerosos pasajes de la historiografía del arte novohispano han corrido la suerte de ser equiparadas e incluso confundidas con los retratos de profesión, al situarlas dentro de la gran clasificación de "monjas coronadas". Lo anterior se debe quizá a la presencia de atributos compartidos, sin embargo, es sabido que sus usos y funciones fueron completamente distintos. Asimismo, es importante señalar que, en su mayoría, los retratos de homenaje ponen el acento en los rasgos de identificación genérica, más que en aquellos que resaltan las características físicas de los personajes. Esto puede constatarse en lo estandarizado de sus facciones, en las que parece no haber particularidades que nos permitan relacionar retratos distintos de una misma religiosa. Es, sin embargo, gracias a los elementos de naturaleza corporativa y simbólica que nos es posible realizar las inferencias correspondientes con respecto a la identidad del personaje representado y, por supuesto, a las cartelas (figura 8).

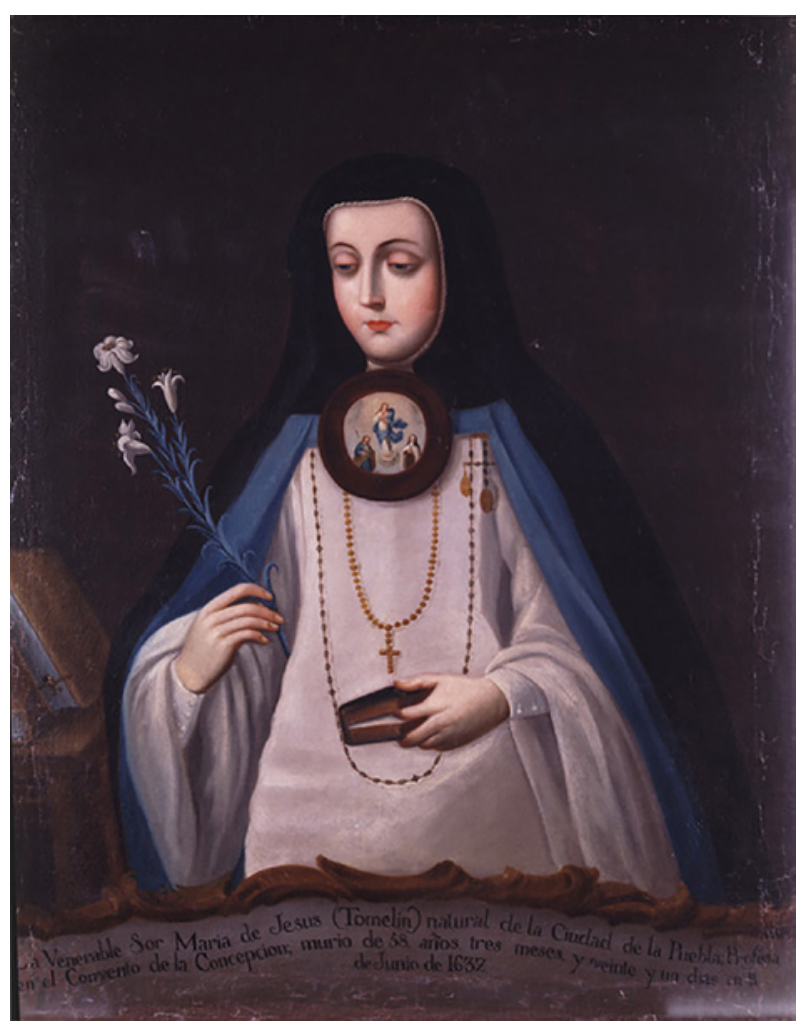

$\rightarrow$ FIGURA 8.

Retrato de la venerable madre María de Jesús Tomelín

Fuente: Colección Museo Nacional del Virreinato. Instituto Nacional de Antropología e Historia, México. 


\section{A manera de conclusión}

En este artículo se ha planteado una ruta de exploración teórica e historiográfica en torno al retrato monjil novohispano, a partir de la necesidad de estudiarlo más allá de la perspectiva formalista dominante que lo ha reducido a criterios relacionados únicamente con su factura, profusión y naturalismo, como ejes para su estudio y validación. En muchos casos estos criterios han marginado sus implicaciones simbólicas, usos y funciones, en cuanto dispositivos susceptibles de activar los sentidos interiores y el sentimiento de pertenencia a una serie de corporaciones cuya especificidad incide directamente en el modo en que se formularon y se decodificaron los mensajes contenidos en ellos. En atención a estas omisiones, se ha analizado la tensión existente entre la presencia individual y la grupal, así como el criterio de semejanza en los retratos inscritos en el contexto monacal novohispano, apelando a la categoría de "retrato corporativo" y ubicando sus fluctuaciones en los momentos de profesión, muerte y homenaje. Asimismo, se ha puesto el acento, de manera general, en el vasto universo de implicaciones simbólicas que poseen algunos de los elementos y atributos recurrentes en los retratos, proponiendo una alternativa a la tendencia historiográfica que ha solido apostar tan solo por sus cualidades decorativas. De acuerdo con lo anterior, se ha propuesto un análisis que sin dejar de poner atención en lo formal, considere también las fuentes escritas y sobre todo el modo en el que los distintos carices determinaron la vida cotidiana y espiritual de las religiosas, ambos factores determinantes al momento de formular soluciones pictóricas, usos, funciones y lecturas en torno a sus retratos. De este modo, se concluye que las representaciones de profesión, muerte y homenaje deberán concebirse como "imágenes" en un sentido más amplio, en cuanto semejanzas incorpóreas de un cuerpo colectivo y simbólico que, si bien se perciben mediante los sentidos corporales, se albergan en el depósito interior, para patentizarse en el propio espíritu. 


\section{$\infty$ \\ B I B L I O G R A F í A}

\section{F U E N T ES PR I MAR I A S}

\section{A. Impresos}

Bellido, Joseph. Vida de la V. M. R. M. María Anna Agueda de S. Ignacio, primera priora del Religiosísimo Convento de Dominicas recoletas de Santa Rosa de la Puebla de los Ángeles. México: Imprenta de la Bibliotheca Mexicana, 1758.

De Lemus, Diego. Vida, virtudes, trabajos, favores, y milagros de la Ven. M. Sor María de Jesús Angelopolitana. León: A Costa de Anisson, y Posuel, I683.

De Santander, Sebastián. Vida de la Venerable María de San Joseph. México: Herederos de la Viuda de Miguel de Rivera, 1723.

Pacheco, Francisco. Arte de la pintura, su antigüedad y grandezas. Libro primero. Sevilla: Francisco Faxardo, 1649.

Paleotti, Gabrielle. Discorso intorno alle aimmagini sacre e profane. Milán: Librería Editrice Vaticana, 1582 .

Palomino, Antonio. El museo pictórico, y escala óptica. Tomo I. Madrid: Lucas Antonio de Bedmar, i7 I5.

Salmerón, Pedro. Vida de la venerable Madre Isabel de la Encarnación, carmelita descalza, natural de la Ciudad de los Ángeles. México: Francisco Rodríguez Lupercio, 1675.

\section{I FU E N T ES S C U N D A I A S}

Báez, Linda. "Reflexiones en torno a las teorías de la imagen en Alemania: la contribución de Klaus Sachs-Hombach”. Anales del Instituto de Investigaciones Estéticas, n. ${ }^{\circ}$ 97, 2010 , p. 157-194. https://doi.org/10.22201/iie.18703062e.2010.97.2316

Bieñko de Peralta, Doris. "Las verae efigies y los retratos simulados. Representaciones de los venerables angelopolitanos, siglos XVII y XVIII". La función de las imágenes en el catolicismo novohispano, editado por Gisela Von Woebeser, Carolina Aguilar García y Jorge Luis Merlo Solorio. México: IIH-UnAM, 2018, pp. 255-282.

Civil, Pierre. "Retratos milagreros y devoción popular en la España del siglo XviI (Santo Domingo y San Ignacio)". Actas del V Congreso Internacional de la Asociación Internacional Siglo de Oro (AISO), 1999, pp. 350-360. https://doi.org/10.31819/9783964564894-032 
Doménech García, Sergi. "Vestidas a la espera del esposo. Imagen y liturgia de la virginidad consagrada en los retratos de monjas”. Congreso Internacional Imagen Apariencia. Noviembre I9, 2008 - noviembre 21, 2008. Münster: Universidad de Murcia, 2008, pp. I-I 4.

El sacrosanto y ecuménico Concilio de Trento. Traducido por Ignacio López de Ayala. Barcelona: Imprenta de Benito Espona, 1847.

Gubern, Román. La mirada opulenta. Exploración de la iconósfera contemporánea. Barcelona: Gustavo Gill, 1987.

Jay, Martin. Campos de fuerza: entre la historia intelectual y la critica cultural. Buenos Aires: Paidós, 2003.

Lavrin, Asunción. Las esposas de Cristo. La vida conventual en la Nueva España. México: Fondo de Cultura Económica, 2016.

Ledesma, María. "Régimen escópico y lectura de imágenes”, UNER, 2005, pp. I-IO. http:// www.fcedu.uner.edu.ar/clm/ledesma.html. Consultado en enero del 2018.

Maroto, Daniel. “Teología y espiritualidad de los carismas”. Salmaticensis, n. ${ }^{\circ}$ 60, 20I3, pp. 453-48I. https://doi.org/10.36576/summa.32516

Montero Alarcón, Alma. Monjas coronadas. Profesión y muerte en Hispanoamérica virreinal. México: Plaza y Valdés, 2008.

--.. "Pinturas de monjas coronadas en Hispanoamérica”. Monjas coronadas. Vida conventual femenina en Hispanoamérica, editado por Sara Baz. México: INAH, 2003, pp. 48-68.

Monterrosa Prado, Mariano. "La corona”. La conservación de las coronas de monjas del Museo de Arte Religioso Ex Convento de Santa Mónica, Puebla, editado por Judith Katia Perdigón Castañeda. México: INAH, 20II, pp. 59-74.

Mues Orts, Paula. "Corporate Portraiture in New Spain. Social Bodies, the Individual, and their Spaces of Display". New England/New Spain. Portraiture in the Colonial Americas, 1492-I850, editado por Donna Pierce. Denver Art Museum, 2016, pp. 8I-IOI.

Mujica Pinilla, Ramón. Rosa limensis. Mistica, politica e iconografía en torno a la patrona de América México: IFEA, CEMCA, FCE, 2005.

Muriel, Josefina y Manuel Romero de Terreros. Retratos de monjas. México: Editorial Jus, 1952.

Muriel, Josefina. “Los retratos que conocemos”. Retratos de monjas. México: Editorial Jus, I952, pp. 33-43

Portús, Javier. "Retrato, humildad y santidad en el Siglo de Oro". Revista de Dialectología y Tradiciones Populares, tomo 54, 1991, pp. 169-188.

Rubial, Antonio. La santidad controvertida. México: Fondo de Cultura Económica, 1999.

Ruiz Gomar, José Rogelio. “Catálogo de la colección de retratos de monjas”. Monjas coronadas, editado por Fides Ruiz de Velasco. México: Presidencia de la República, 1978, pp. 37-83. 